\title{
Periodontal Ehlers-Danlos syndrome
}

INSERM

\section{Source}

INSERM. (1999). Orphanet: an online rare disease and orphan drug data base.

Periodontal Ehlers-Danlos syndrome. ORPHA:75392

Ehlers-Danlos syndromes (EDS) form a heterogeneous group of hereditary connective tissue diseases characterized by joint hyperlaxity, cutaneous hyperelasticity and tissue fragility. 